\title{
Accountability in government programmes to promote small and medium-sized enterprises
}

\section{Mario Castillo}

Director of

High Technology Investments,

Chilean Economic

Development Agency (CORFO),

Santiago, Chile

mcastillo@corfo.cl

Roy C. Nelson

Associate Professor,

Thunderbird,

The American Graduate School of International Management, Glendale, Arizona

nelsonr@t-bird.edu
A potential threat to the effectiveness of institutions in Latin

America promoting small and medium-sized enterprise

(SME) development is that these programmes might become clientelistic agencies, advancing interests other than the welfare of the SMEs themselves. As governments in Latin America have adopted more market-oriented policies, however, government institutions in the region that promote SMEs are undergoing a similar transformation. Our hypothesis is that two factors, the extent to which an institution has adopted market-oriented practices and its degree of autonomy (both from government and from societal interest groups), are what determine its level of accountability, as measured by the extent to which the institution conducts systematic, independent evaluations of the impact of its programmes. The four cases examined here (SEBRAE in Brazil, NAFIN in Mexico, CORFO in Chile and SEPYME in Argentina) show that the hypothesis is valid for government institutions, but less so for private institutions with assured budgets. 


\section{Introduction}

For a number of reasons, governments in Latin America have long promoted the development of local small and medium-sized enterprises (SMEs). Governments do this primarily because SMEs provide employment ${ }^{1}$ and contribute to local economic growth and development. Nevertheless, a potential threat to the effectiveness of institutions in Latin America promoting SME development is that these programmes might become clientelistic agencies, advancing the interests of individual politicians rather than the welfare of the SMEs themselves. As governments in Latin America have adopted more market-oriented policies, however, government institutions in the region that promote SMEs are undergoing a similar transformation. Our hypothesis is that two factors, the extent to which these institutions have adopted market-oriented practices and their degree of autonomy (both from the government and from societal interest groups), are what determine their level of accountability, as measured by the extent to which the institution conducts systematic, independent evaluations of the impact of its programmes. This article examines and compares the practices and organizational structure of four different institutions -the Secretariat for Small and Medium-sized Enterprises (SEPYME) in Argentina, the Brazilian Assistance Service for Micro and Small Enterprises (SEBRAE) in Brazil, the Chilean Economic Development Agency (CORFO) in Chile and Nacional Financiera, S.N.C. (NAFIN) in Mexico- in order to assess the validity of this hypothesis.

\section{II}

\section{The theoretical context}

Debates about the role of SMEs in Latin America have continued since the International Labour Organization (ILO) published an early study on SMEs in Kenya in 1972 (ILO, 1972). In the 1980s, one influential study by the Economic Commission for Latin America and the Caribbean (ECLAC) concluded that there was an enormous gap between the hopes governments in Latin America placed in these types of firms, and the available evidence of their genuine potential. ${ }^{2}$ As larger

\footnotetext{
${ }^{1}$ SMEs employ between $40 \%$ and $50 \%$ of the workforce in Latin America (see Alburquerque, 1997, p. 155). Small and medium-sized manufacturing accounts for a large share of employment in the manufacturing sector: 45\% in Argentina (1993), 67\% in Brazil (1997), 53\% in Chile (1996) and 45\% in Mexico (1993), according to Peres and Stumpo, 2000, pp. 1643 to 1655.

2 According to the overall information for Latin America in the 1980s, SMEs had a very limited position in the economic structure, showed a preference for domestic markets, and generally did not play a leadership role in the economic, political or institutional spheres. SMEs were usually oriented towards mass consumer goods, the utilization of rudimentary technology, and lack of interenterprise cooperation. Within firms, these factors give rise to many
}

enterprises developed technologically, SMEs played an ever smaller role in the region's economic development. Although this problem resulted from a number of factors, the growing productivity gap between larger enterprises and SMEs was probably most important. However, another part of the problem was that, increasingly, SMEs were either not part of the more efficient, more technologically adept larger enterprises' production processes at all, or participated in them only in a subordinated way, as "junior partners" to the larger firms.

A recent study that describes the performance of small and medium-sized manufacturing enterprises (SMMEs) in 10 Latin American countries since the second half of the 1980s under the "new economic model" comes to three controversial conclusions (Peres and Stumpo, 2000). First, macroeconomic conditions

problems, including inadequate production conditions, an extraordinarily conservative management approach, a detrimental form of dependency on input and product markets, problems with access to financing and a low level of manpower skill. 
have been the main determinants of SMME performance; second, trade liberalization has had a strong impact on sectoral restructuring within SMME production; and third, the effects of public policies aimed at fostering SMME development can be eliminated as an important factor. According to this study, in most countries, with the exception of Brazil and Mexico, public policies have had little impact because of a lack of financial and human resources and fragmented decision-making among government agencies.

While we would agree with the importance of macroeconomic conditions and the level of trade liberalization in promoting SME development, we would argue that the nature of the public agencies promoting SMEs can also have an impact. Whether the impact is positive or negative depends upon the specific characteristics and policies of the agency concerned.

As late as the $1980 \mathrm{~s}$, traditional government programmes to support the development of SMEs consisted largely of direct subsidies. The usual kind of subsidy consisted of loans with easy terms, such as low interest rates and long repayment periods. Since these were loans from the government, rather than commercial banks, many SMEs found that they could renegotiate the terms or postpone making payments. In this period, the majority of the national development banks in Latin America had a high-risk exposure with a low quality of loan portfolio. Over time, policy makers realized that making government loans to SMEs was not an effective policy. ${ }^{3}$

In response to these difficult lessons, as well as to the new consensus in Latin America in favour of economic restructuring, government officials decided that they would not only have to restructure government institutions designed to promote SMEs, but would also have to reformulate their policies towards SMEs.

In Brazil, CEBRAE (Brazilian Support Centre for Small and Medium-sized Enterprises), the government institution promoting SMEs, became SEBRAE (Brazilian Assistance Service for Micro and Small Enterprises), a private agency, in 1990. In Chile, CORFO (Chilean Economic Development Agency) began its own restructuring in 1990. In Mexico, NAFIN (Nacional

\footnotetext{
${ }^{3}$ The traditional policies to support SMEs consisted of direct State action through State financial agencies, which channelled credit to SMEs at subsidized interest rates. The poor performance of these policies resulted from the emphasis on subsidized credit and the poor management of loan portfolios. This situation required many institutions to undergo financial restructuring (see Castillo, 1993; Held, 1995).
}

Financiera, S.N.C.) began this transformation in 1989. In Argentina, lastly, Congress approved a special law in 1995 (Estatuto legal para las pyme) to promote SMEs. In 1997, SEPYME (Secretariat for Small and Mediumsized Enterprises) was created under the direct authority of the President.

All of this was consistent with the so-called "Washington Consensus" on economic reform in Latin America - a term United States economist John Williamson had coined to denote the set of marketoriented policies favoured by Washington, D.C. based institutions such as the IMF and the World Bank (Williamson, 1990).

Some Latin American authors, while agreeing on the importance of market-oriented policies, argued that there were some important differences between the views in Washington and Latin America on this topic. The IMF, for example, concerned with budget deficits, tended to maintain that government spending generally was anathema to reform, and government programmes should be cut across the board. At least some Latin American policy makers argued, however, that some government spending -for example, spending on programmes to promote SMEs- could, if the SMEs prospered, eventually bring in more tax revenues and enhance a country's fiscal situation in the long run (Pereira, 1992; Edwards, 1995). Reducing government "bloat" and inefficiency was essential, the Latin American authors argued; but indiscriminate cuts in spending programmes were not necessarily warranted or a good idea for a country's long-term economic development. $^{4}$

Regardless of these differing views, the new, more market-oriented approach meant that as government institutions cut their budgets and reduced their payrolls, the kinds of economic programmes they advocated changed as well. Now, the emphasis was on providing financial services through the private banking system (rather than direct loans from government institutions). Also, increasingly, government institutions sought to develop a different model for action altogether by providing non-financial services (sometimes known as "business development services", or BDS). Such services included providing technical assistance, promoting technological innovation, and facilitating business linkages.

The prevailing Washington Consensus compelled government institutions to reform their structures and

\footnotetext{
${ }^{4}$ In the context of the Argentine crisis, policy makers are questioning the Washington consensus ever further.
} 
policies. In the same way, the Committee of Donor Agencies for Small Enterprise Development (also known as the Donor Committee) was also influential in bringing about this emphasis on the part of government institutions to provide non-financial services. The Donor Committee was composed of representatives from international institutions, such as the World Bank, the Inter-American Development Bank (IDB) and the International Labour Organization (ILO), that work to promote the development of SMEs. In the mid-1990s, this organization helped define the standards for best practices in financial services. In the late 1990s, the Donor Committee devised a preliminary set of guidelines for best practices in non-financial services. However, non-financial services include a wider array of activities than financial services. Therefore, it has been more difficult for the Donor Committee to offer fixed guidelines for such activities. ${ }^{5}$

Nevertheless, those working in this field are well aware that certain principles and practices are more likely to be effective than others. Most important, any institution working to promote development of SMEs in Latin America should be market-oriented, i.e., should have the specific needs of the clients themselves (rather than some narrow political objective) in mind. Despite the new consensus in favour of market-oriented policies and practices in Latin America, some SME programmes still fall short of achieving this goal. Moreover, some lack institutional autonomy from government. These two factors, we maintain, are important in determining the level of accountability of these organizations, which is central to an agency's overall effectiveness.

The model we have developed (see section IV below) seeks to explain the factors that lead to accountable government programmes to promote the development of SMEs in Latin America. Before proceeding to a more specific discussion of the model, however, we provide in the next section further background and political context on the four institutions we assess in this article. This is important in order to understand the current structure of these institutions and the political, economic and organizational context in which they have been operating since experiencing the dramatic changes in Latin America in the last decade. While each institution has been transformed by these changes, each has also emerged with somewhat different organizational structures. Once we have explained these differences, we can present the model, which shows how these different structures affect each institution's level of accountability.

\section{III}

\section{The changing institutional environment}

\section{The challenge of institutional transition}

The transformation of development institutions in Latin America began with the process of financial liberalization that started in the 1970 s. As the deficiencies of the structuralist ${ }^{6}$ governmentinterventionist model for economic development

\footnotetext{
${ }^{5}$ Other organizations, such as the Organisation for Economic Cooperation and Development (OECD), through its Forum for Enterprise Development, have encouraged the dissemination of best practices related to finance, regulatory frameworks, taxation policies, business networks, support services, e-commerce and cross-border cooperation, among others (see OECD, 2002).

${ }^{6}$ The structuralist vision of the saving-investment process encouraged policy makers to work towards a structural transformation of the economy, implementing tax policies to increase income tax revenues, establishing tax incentives for investment, and creating "developmentalist" financial corporations (see Rosales, 1988).
}

became more evident, the need for financial liberalization was clear. By the mid-1970s, most Latin American policy makers agreed that one of the principal causes of Latin American countries' low saving rates was excessive government control of the financial system, notably government control over credit allocation and interest rates.

At the beginning of the 1980s, Latin American governments began to focus their efforts on restructuring their development banks in the context of economic liberalization and the reform of the financial system. Some countries, such as Chile and Argentina, began this process early; others, such as Brazil and Mexico, ${ }^{7}$ have undertaken it more recently. Since the

\footnotetext{
${ }^{7} \mathrm{An}$ analysis of the role of development banks in the context of financial liberalization in Argentina, Brazil, Chile, and Mexico can be found in ALIDE (1993).
} 
1990s, development institutions have not only reduced their role in direct financing of development activities, but have also begun to offer an array of non-financial services.

In each country, government SME development agencies have undergone a different kind of restructuring. While Brazil, as mentioned earlier, chose to privatize its SME development agency, CEBRAE (now known as SEBRAE), Mexico decided to modernize its development bank, NAFIN, but still keep it under government control. In Chile, CORFO transferred administrative duties of its SME programmes to private intermediaries (the CORFO network), while Argentina's SEPYME was designed to maintain coordination of a number of SME promotion activities under the direct control of the Executive Branch.

In Brazil, the Collor administration terminated several government-run SME programmes. In April 1990, the government SME institution, CEBRAE, was privatized and renamed SEBRAE. While private, SEBRAE was financed by a $0.3 \%$ government payroll tax levied on firms in Brazil. SEBRAE's new role was to assist SMEs seeking to improve their organization, management, technological capability and creditworthiness (Suzigan and Villela, 1997). A non-profit institution, SEBRAE has its headquarters in Brasilia and another 27 offices (one located in each of Brazil's 26 states, plus the federal district).

SEBRAE's structure makes it original and distinct from other institutions promoting SMEs in Latin America. Although, technically, SEBRAE's funding still comes from the government by means of the payroll tax on firms, the amount provided to SEBRAE is not subject to political debate in Brazil's Congress, or to the political whims of Brazil's president, and SEBRAE is in no other way linked to the federal government. The amount is $0.3 \%$ of Brazilian firms' payroll in any given year. This insulates SEBRAE from political debate over the nature of its activities. The Brazilian government cannot withhold funding from SEBRAE unless it changes the $0.3 \%$ financing law by an act of Congress. In comparison with the other cases considered here, SEBRAE has a high level of autonomy over its budget as well as in its decision-making.

In Mexico, as a result of the country's new economic model, NAFIN has been subject to deep changes in practically all areas. In 1989, NAFIN initiated a modernization programme under the framework for consolidating financial intermediaries. After 55 years as a traditional development bank, NAFIN underwent a restructuring that included many austerity measures
(NAFIN, 1998). While remaining a government institution, NAFIN is seeking to become a modern development bank, working to promote new financial intermediaries, to bring venture capital to develop new investment, and to provide non-financial services for SMEs such as technical assistance and training. Under Mexico's laws, NAFIN's board is composed primarily of government officials and remains under the control of the government. The principal sources of NAFIN's budget, as NAFIN itself indicates in its annual report (NAFIN, 1997, p. 14), are loans from international development institutions such as the World Bank and IDB, lines of credit from foreign banks, and the placement of securities in the domestic and international markets.

Thus, NAFIN is a case of an institution that has its own independent budget, yet still remains under government control. The decision-making process in NAFIN remains largely under the control of central government through NAFIN's government-appointed board of directors. Of the cases considered in this article, NAFIN represents a high level of budgetary autonomy, but a low level of decision-making autonomy.

In Chile, CORFO, created in 1939, was at one time a traditional development bank as well as a holding company for public enterprises. However, in the last 10 years CORFO has undergone a major restructuring. In 1990, CORFO decided to end its direct action as a financial institution. Its goal thenceforth was to provide, through the private financial system, long-term resources to the business sector that were compatible with the development of investment projects. In 1992, CORFO began to develop new programmes for the modernization of SMEs. The main programmes were promotion of technological innovation, cooperative development and technical assistance. Since 1993, CORFO has systematically transferred the administrative duties of these mechanisms and the allocation of its resources to private intermediaries in order to attain greater efficiency and coverage in its activities. ${ }^{8}$

Like NAFIN, CORFO has some assets of its own. It can obtain loans from international lending institutions.

\footnotetext{
${ }^{8}$ In 1997, consistent with this objective, Chile's laws regarding CORFO were modified. Under the new arrangements, CORFO's Board now includes representatives from the private sector, as well as representatives from the agricultural and foreign ministries. CORFO has now outsourced the management of its company holdings to a separate committee, and CORFo itself is devoted entirely to promoting SMEs.
} 
However, the Chilean Congress must approve CORFO's annual budget. In relation to the other cases considered here, CORFO represents an intermediate level of autonomy from the central government, in terms of both its budget and its decision-making capability.

In Argentina, many different public institutions -such as the Ministry of the Economy, the Secretary of Industry, Commerce, and Mining and the Federal Investment Council, among others- used to have a number of separate programmes to promote SMEs. In 1995, the Argentine Congress approved the "SME statute". This law focused on technical and financial assistance for SMEs and a system of reciprocal guarantees and labour relations for these firms. In order to put this law into effect, the Executive Branch created a special secretariat called SEPYME in 1997.

SEPYME's purpose was to coordinate the Argentine government's various SME programmes. In the beginning, SEPYME had the status of a ministry and was under the direct authority of the President of Argentina. Its budget served only to support its activities in coordinating the other government SME programmes, not actually to implement these programmes. Also, although SEPYME had political authority over SME programmes, it lacked administrative authority over personnel working in the various ministries that were charged with executing them. Therefore, while SEPYME lacked autonomy from the government in its budget and its decision-making process, its autonomy was further weakened by its lack of direct control and responsibility over the programmes it coordinated. Of the cases analysed here, SEPYME represents a very low level of both budgetary and decision-making autonomy. Although SEPYME is now under the authority of the Ministry of Production, it still possesses less autonomy from the government than the other institutions we analyse here.

\section{Multilateral institutions: guidelines for obtaining assistance}

Multilateral institutions, such as the World Bank, IDB and the Donor Committee, have an important role in designing, implementing and financing SME programmes in Latin America. If government institutions want to get financial assistance from any of these organizations, they need at a minimum to comply with the requirements laid down by them. Assistance from multilateral organizations is often part of a package, all of which is conditional upon meeting certain objectives, such as structural adjustment and economic reform.

Significantly, by the mid-1990s the World Bank, one of the main institutions that Williamson (1990) had defined as being part of the Washington Consensus, had begun to emphasize the importance of institutions in promoting economic competitiveness. Noting the success of East Asian countries during the previous three decades, where the State had a key role in promoting economic development, the World Bank began to rethink the role of the State in this process. This new thinking was reflected in the 1993 World Bank study, East Asian Miracle (World Bank, 1993). Recent World Bank publications have continued to emphasize the importance of the State in promoting development, and have explicitly referred to shortcomings in the old approach with such titles as Beyond the Washington Consensus: Institutions matter (Burk and Perry, 1998) and More instruments and broader goals: Moving toward the post-Washington consensus (Stiglitz, 1998).

IDB is the most important donor agency providing resources to institutions that promote SMEs in Latin America. Table 1 indicates the extent of that support for each of our country cases.

Multilateral institutions transfer not only money but also best practices. The Donor Committee, for example, has a clear vision of what it considers to be the best practices for SME programmes in Latin America. In its 1997 report on business development services for SMEs, it listed numerous guidelines, all related to the overarching aim of developing "business-like organizations", that institutions working to provide nonfinancial business development services should follow. These include developing a "business-like vision and corporate culture", "a high degree of autonomy from government", "management systems to introduce or simulate market mechanisms" and "the technical capacity to adapt or develop new products" (The Donor Committee, 1997). Although these guidelines are clearly part of the institutional environment in which SME programmes are designed, it is difficult to know the exact influence that they have on government institutions in Latin America. 
TABLE 1

Inter-American Development Bank (IDB): Activities supporting SMEs, 1990-1998

(Millions of dollars)

\begin{tabular}{|c|c|c|c|c|c|}
\hline & Brazil & Chile & Mexico & Argentina & Total \\
\hline Financial support ${ }^{\mathrm{a}}$ & 550 & 358 & 587 & 300 & 1,795 \\
\hline Non-financial support ${ }^{\mathrm{b}}$ & 250 & 40 & 250 & 254 & 794 \\
\hline Science and technology $\mathrm{c}$ & 160 & 68 & 180 & 95 & 503 \\
\hline $\begin{array}{l}\text { Loan support and } \\
\text { regulatory reform }\end{array}$ & - & $150^{\mathrm{d}}$ & $250^{\mathrm{e}}$ & $675^{f}$ & 1,075 \\
\hline
\end{tabular}

Source: Puente, Llisterri and Rivas (1998).

a Multisectoral credit.

${ }^{\mathrm{b}}$ Business productivity support programmes.

c Science and technology programme.

${ }^{\mathrm{d}}$ Financial reform improving access to formal sources of credit.

e Trade regulation, tariffs, customs and other aspects of the trade system.

${ }^{\mathrm{f}}$ Financial reform, legal framework, trade regulation and business environment.

\section{IV}

\section{The model}

In our model (figure 1), the extent to which the institution promoting SMEs is market-driven (has adopted market-oriented practices) is the independent variable. The autonomy of the institution is the intervening variable. The dependent variable is the institution's level of accountability.

\section{Independent variable}

Because of the strong influence of multilateral lending institutions, there is a widespread consensus about the principles and instruments that institutions promoting SMEs should adopt. This explains why we do not find significant variation between our cases with regard to the independent variable, namely the extent to which the institution promoting SMEs is market-driven. In fact, our analysis shows that each of the four institutions in our study has similar programmes promoting market-oriented policies for SMEs. In order to make this assessment, we examine three major programmes that each institution has developed for promoting SMEs: business consulting, technological development and business networking.

FIGURE 1

Market orientation, autonomy and accountability of institutions promoting SMEs

Market-driven principles

- Performance orientation

- Client focus

- Outsourcing

Independent variable

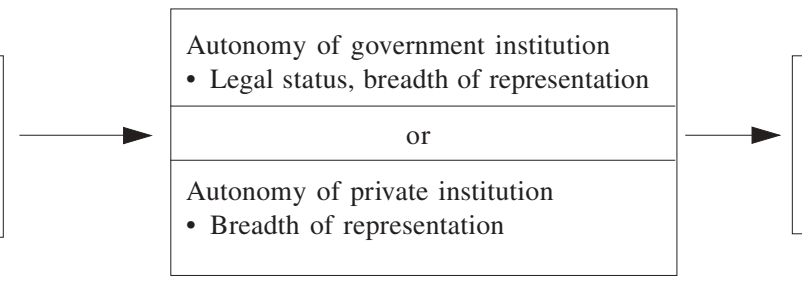

Intervening variable
Accountability

- Accounting of programmes

- Programme evaluations

Dependent variable

Source: Prepared by the authors. 
The measures and indicators we use for assessing the extent of market orientation for each programme are the following:

i) Performance orientation

Indicator: Co-financing. Does the institution practise co-financing of projects?

ii) Client focus

Indicator: Client design. Does the institution incorporate any client designs into its projects?

iii) Outsourcing

Indicator: Outsourcing. Is there outsourcing to private institutions?

\section{Intervening variable}

Although there may be little difference among the institutions with regard to our independent variable, there are important differences in the intervening variable, the level of autonomy of the institution promoting SME development. The four country cases differ widely in this regard.

The level of autonomy of an institution means its ability to implement broad government objectives without becoming captive to the interests of particular groups, either within the government or in society at large, that want to advance their own narrow interests. Given the difficulty with clientelism in Latin America, SME programmes are susceptible to becoming captured in this way by specific interest groups. Our hypothesis is that institutions that can avoid such political interference will have a higher level of accountability, as defined by their conducting systematic, independent evaluations of their own programmes.

We use different measures for the "autonomy" variable in government and private institutions. One aspect of autonomy in government institutions is legal autonomy, or the independence of the institution from government control. A greater degree of independence would make the institution less susceptible to political interference from groups within the government, including the president, seeking to advance narrow political ends. Another measure of autonomy is breadth of representation on the board of directors. A broad representation from different government ministries and the private sector would tend to prevent the institution from becoming "captured" or controlled by particular societal groups pursuing their own interests. Private institutions would tend automatically to have legal autonomy, but would still be prone to being captured by individual societal groups. For private institutions, then, our sole measure for autonomy is the breadth of representation on the institution's board of directors.

The measures and indicators for each kind of institution for the "autonomy" variable are as follows:

\section{a) Government institutions}

i) Legal autonomy

Indicator: Is the institution part of the national government structure (least autonomous), a separate ministry (intermediate autonomy) or a public agency (most autonomous)? ${ }^{9}$

ii) Breadth of representation

Indicator: How broad is the societal representation on the board of directors? Is just one sector represented, or a wide range of sectors? Is there broad private and public representation?

b) Private Institutions

Breadth of representation

Indicator: How broad is the societal representation on the board of directors? Is just one sector represented, or a wide range of sectors? Is there broad private and public representation?

\section{Dependent variable}

For the dependent variable, namely the level of accountability of SME programmes, the indicators are the number and quality of the evaluations the institution does of its own SME programmes. Our assumption is that institutions that are not doing systematic evaluations of their programmes will be less effective at promoting SME development.

The measure and indicators we used are as follows:

a) Accounting of services provided

Indicator: Does the institution provide data/ statistics on what services were provided and where?

\section{b) Programme evaluations}

Indicator: Is there evidence that the institution conducts systematic, independent evaluations of the impact of specific programmes?

\footnotetext{
${ }^{9}$ It would also be useful to have an indicator for the professional capabilities of the institution, such as how many professionals (economists, lawyers, engineers, etc.) work for it and what kind of gap exists between salaries for professionals at a given institution in comparison with professionals in the private sector. However, this information is difficult to obtain. We believe that the legal status indicator is both the most important and sufficient for our purposes here.
} 


\section{The cases of Brazil, Chile, Mexico and Argentina}

\section{Why these countries? Why these institutions?}

Almost every country in Latin America has institutions that promote the development of SMEs. We chose to focus on Brazil, Chile, Mexico and Argentina not only because these are important countries, with large SME programmes, but also because the main institutions working to promote SMEs in these countries have each undergone extensive institutional reform. Currently, each one, while similar in goals, represents a different strategic model of how to promote SMEs.

Since being privatized in 1990, SEBRAE has represented a private model for SME promotion. Its Board of Directors has representatives from both the public and private sector. Mexico's NAFIN is a more traditional government development bank. Although it does have representatives from the private sector on its Board of Directors, government officials on the Board are referred to as "series 'A' advisers", while representatives from the private sector on the Board are referred to as "series 'B' advisers", denoting their lesser status. In contrast, CORFO, Chile's government development agency, has government officials on its Board from several different ministries, plus two representatives from the private sector, appointed by Chile's President. It also uses a very non-traditional approach to promoting SMEs. CORFO serves as a coordinating agency, doing much of its work through private actors that are usually organized into industry associations. SEPYME in Argentina has evolved over time. In the beginning, it was directly under the authority of the President of the Republic, and therefore lacking in autonomy. More recently, it has been reorganized under the authority of the Ministry of Production. Nevertheless, so far it represents a structure that is less autonomous than the other institutions considered here.

As table 2 shows, each of the four institutions, while similar in some ways, differ considerably with regard to their legal structure.

With regard to legal structure, at one extreme is SEBRAE, a private corporation providing its own services, not only to small firms but to microenterprises as well. This structure gives the organization significant independence from the government, yet institutional clout at the same time. At the other extreme is SEPYME, which operates only as a coordinator of other agencies.

In comparing the four institutions, we found that each had programmes that were similar, both in title and content. We examined three of the main programmes: business consulting, technological development and business networking. Table 3 summarizes key features of these programmes in each country. The table shows, first, that the four institutions analysed had very similar non-financial programmes, and they all had business consulting and business networking programmes. Only NAFIN in Mexico did not have technological development programmes. These institutions seem to be adopting very similar sorts of "best practices", as advocated by the Donor Committee.

It is significant that even the wording of these programmes is similar. The point is that they are all fairly similar in the extent to which they are marketdriven. Our focus, therefore, is on the significant differences in the intervening "autonomy" variable.

TABLE 2

Institutional framework for SME development

\begin{tabular}{llll}
\hline Country/Institution & Category & Legal structure & Focus \\
\hline Brazil/SEBRAE (1990) & Non-financial services agency (NFSA) & Private corporation & Micro and small firms \\
Chile/CORFO (1939) & NFSA and development bank & Public corporation & Small and medium-sized companies \\
Mexico/NAFIN (1934) & NFSA and development bank & National credit agency & Small and medium-sized companies \\
Argentina/SEPYME (1997) & Coordinator agency & Sub-cabinet-level agency & Small and medium-sized companies \\
\hline
\end{tabular}

Source: Prepared by the authors. 
TABLE 3

Latin America (four countries): Main SME development

programmes, by country and category

\begin{tabular}{|c|c|c|c|c|}
\hline Programme & Brazil & Chile & Mexico & Argentina \\
\hline $\begin{array}{l}\text { Business } \\
\text { consulting }\end{array}$ & $\begin{array}{l}\text { Programmes for } \\
\text { entrepreneur } \\
\text { development }\end{array}$ & $\begin{array}{l}\text { Promotion projects } \\
\text { (PROFOs) }\end{array}$ & $\begin{array}{l}\text { Training and technical } \\
\text { assistance programme } \\
\text { (COMPITE) }\end{array}$ & $\begin{array}{l}\text { Business reorganization } \\
\text { programme for exporters } \\
\text { (PRE) }\end{array}$ \\
\hline $\begin{array}{l}\text { Technological } \\
\text { development }\end{array}$ & $\begin{array}{l}\text { Technological support } \\
\text { for micro and small } \\
\text { enterprises (PATME) }\end{array}$ & $\begin{array}{l}\text { Technological and } \\
\text { productive development } \\
\text { fund (FONTEC) }\end{array}$ & No programme ${ }^{a}$ & $\begin{array}{l}\text { Argentine technology } \\
\text { fund (FONTAR) }\end{array}$ \\
\hline $\begin{array}{l}\text { Business } \\
\text { networking }\end{array}$ & $\begin{array}{l}\text { Supplier qualification } \\
\text { programme }(\mathrm{CF})\end{array}$ & $\begin{array}{l}\text { Supplier development } \\
\text { programme (PDP) }\end{array}$ & $\begin{array}{l}\text { Supplier } \\
\text { programme (PP) }\end{array}$ & $\begin{array}{l}\text { Supplier development } \\
\text { programme (PDP) }\end{array}$ \\
\hline
\end{tabular}

Source: SEBRAE: http://www.sebrae.com.br; CORFO: http://www.corfo.cl; NAFIN: http://www.nafin.com/portalnf; sEPYME: http:// www.sepyme.gov.ar.

a Although NAFIN itself does not have a specific programme on technological development of SMEs, Mexico does have such programmes, notably the Subsistema de Desarrollo Tecnológico del Sistema de Centros operated by the Ministry of Public Education (SEP) and the National Council for Science and Technology (CONACYT).

\section{VI}

\section{Results}

The tables below provide a summary of our findings on each institution, organized according to independent, intervening, and dependent variables. We elaborate further on these results in Section VII.

With regard to the independent variable, all the institutions appear to be market-driven, at least in the three areas we examined (business consulting, technological development and business networking), as table 4 shows. In assessing the criteria used to determine the extent to which each institution is marketdriven, we found a great deal of similarity. Other than

\section{VII}

\section{Conclusions}

In each country, it is possible to see an institutional transition. The institutions have transformed themselves to become more market-driven, and by and large they have achieved this goal. Of course, each institution appears to have employed a different model to achieve this outcome. Before, Argentina's SEPYME operated as the lack of outsourcing by Argentina's SEPYME, there really is very little variation in terms of degree of market orientation across cases.

With regard to the intervening variable, degree of autonomy, there is considerably more variation (table 5).

Table 6, which gives results for the dependent variable (level of accountability), shows that Chile's CORFO has the highest level of accountability, while Argentina's SEPYME has the lowest. Brazil's SEBRAE and Mexico's NAFIN are in the intermediate range. a sub-cabinet-level agency, directly under the authority of the President. Currently, it is under the authority of the Ministry of Production and coordinates other agencies to carry out SME programmes. Mexico's NAFIN is still in the process of restructuring itself from a traditional development bank into a more modern one 
TABLE 4

Independent variable: degree to which SME development institutions are market-driven

\begin{tabular}{|c|c|c|c|}
\hline $\begin{array}{l}\text { Measure: } \\
\text { Indicator: }\end{array}$ & $\begin{array}{l}\text { Performance orientation } \\
\text { Co-financing }\end{array}$ & $\begin{array}{l}\text { Client focus } \\
\text { Client design }\end{array}$ & $\begin{array}{c}\text { Market mechanisms } \\
\text { Outsourcing }\end{array}$ \\
\hline \multicolumn{4}{|l|}{ SEBRAE/Brazil } \\
\hline Business consulting & YES & YES & YES \\
\hline Technological development & YES & YES & NO \\
\hline Business networking & YES & YES & NO \\
\hline \multicolumn{4}{|l|}{ CORFO/Chile } \\
\hline Business consulting & YES & YES & YES \\
\hline Technological development & YES & YES & NO \\
\hline Business networking & YES & YES & YES \\
\hline \multicolumn{4}{|l|}{ NAFIN/Mexico } \\
\hline Business consulting & YES & $\ldots$ & $\mathrm{NO}$ \\
\hline Technological development & $\ldots$ & $\ldots$ & $\ldots$ \\
\hline Business networking & YES & YES & $\mathrm{NO}$ \\
\hline \multicolumn{4}{|l|}{ SEPYME/Argentina } \\
\hline Business consulting & YES & YES & YES \\
\hline Technological development & YES & YES & NO \\
\hline Business networking & YES & YES & NO \\
\hline
\end{tabular}

Source: SEBRAE: http://www.sebrae.com.br; CORFO: http://www.corfo.cl; NAFIN: http://www.nafin.com/portalnf; sEPYME: http:// www.sepyme.gov.ar.

TABLE 5

Intervening variable: Degree of autonomy enjoyed by SME development institutions

\begin{tabular}{llll}
\hline Country/Institution & Indicators of autonomy & & Degree of autonomy \\
\hline & Legal status & Breadth of representation on the board \\
Brazil/SEBRAE & Private & Broad representation & High autonomy \\
Chile/CORFO & Public & Medium-high representation & Medium autonomy \\
Mexico/NAFIN & Public & Medium-low representation & Low autonomy \\
Argentina/SEPYME & Public & Directly under President/Ministry & Very low autonomy
\end{tabular}

Source: SEBRAE: http://www.sebrae.com.br; CORFO: http://www.corfo.cl; NAFIN: http://www.nafin.com/portalnf; SEPYME: http:// www.sepyme.gov.ar.

TABLE 6

\section{Dependent variable: level of accountability}

\begin{tabular}{|c|c|c|c|}
\hline Country/Institution & $\begin{array}{c}\text { Accounting of } \\
\text { services provided }\end{array}$ & $\begin{array}{l}\text { Evaluations of impact } \\
\text { of specific programmes }\end{array}$ & $\begin{array}{c}\text { Level of } \\
\text { accountability }\end{array}$ \\
\hline Brazil/sEBRAE & YES & NO & Medium \\
\hline Chile/CORFO & YES & PROFOS, FAT, FONTEC (independent, outsourced evaluations) & High \\
\hline Mexico/NAFIN & YES & NO & Medium \\
\hline Argentina/SEPYME & NO & NO & Low \\
\hline
\end{tabular}

Source: SEBRAE: http://www.sebrae.com.br; CORFO: http://www.corfo.cl; NAFIN: http://www.nafin.com/portalnf; sEPYME: http:// www.sepyme.gov.ar. 
that works through intermediary agencies and also incorporates non-financial services into its sphere of activity. Chile's CORFO, once a traditional development bank that increased its level of autonomy, now operates almost completely through private financial and nonfinancial intermediaries. Lastly, Brazil's SEBRAE is a unique experiment in Latin America: it is the first government institution promoting SMEs to have become a private organization. While all these institutions have chosen different models or strategies to pursue their objectives, we can safely say that they have all become market-driven institutions.

With regard to the intervening variable, the results mostly confirm our expectations. We hypothesized that the degree of autonomy (table 5) would determine the level of accountability of the institutions promoting SMEs. As it turns out, Chile's CORFO, whose medium level of autonomy is the highest of any of the three public institutions', also has the highest level of accountability. It provides multiple, systematic, independent evaluations of its programmes. It actually outsources the evaluation of its programmes to universities in a competitive bid process in order to ensure that the evaluations will be independent and unbiased. Argentina's SEPYME, in contrast, with the lowest levels of autonomy, has the lowest level of accountability. Indeed, it does not even provide an accounting of the number of SMEs it assists, the quantity of the services it provides to them, etc. In an intermediate position is Mexico's NAFIN, which has a low level of autonomy. Since it does keep track of the SMEs it assists, but does not do independent evaluations, we classify it as having a medium level of accountability. These are the sorts of results our hypothesis had predicted.

Brazil's SEBRAE, however, represents a paradox. Although it has a high level of autonomy, it has only a medium level of accountability. Upon reflection, however, the reason seems obvious. SEBRAE is a private institution with an assured budget, based on the $0.3 \%$ payroll tax on Brazilian businesses. It does not have to make a budget proposal every year as government institutions do, and compete for its allocation of resources. Therefore, SEBRAE does not have an incentive to provide systematic, independent evaluations of the impact of its programmes.

Like government agencies, however, SEBRAE must spend the full amount of money it receives every year; if not, Brazil's Congress might decide to reduce the payroll tax in future years. One way to do this would be to spend the resources on a large number of programmes, not only those for SMEs but also programmes to promote microenterprise development. This might explain why SEBRAE has such a broad "coverage": it has programmes for $17 \%$ of all SMEs and microenterprises in the country, as compared to smaller numbers for NAFIN (14\%) and CORFO (10\%), which focus on SMEs (figures for SEPYME are not available) (Peres and Stumpo, 2002). Without systematic studies, however, there is no way to ascertain the impact of this coverage with any certainty. Indeed, SEBRAE may provide broad coverage but with low impact or results. Without greater accountability, it is impossible to know for sure.

Chile's CORFO represents an alternative model of autonomy. In the case of CORFO, the government retains control of the institution and defines its overall strategic objective. At the same time, however, CORFO maintains a degree of legal autonomy because it is organized as a public corporation, with its own budget and decisionmaking capabilities. In addition, CORFO's Board of Directors is composed of a broad range of representatives from the private sector as well as from a number of different government ministries. Lastly, CORFO operates almost entirely through private intermediaries to carry out its work. This structure gives the institution a great deal of independence from government political interference, enabling it to carry out its objectives in a highly systematic and effective manner. It also explains CORFO's high level of accountability: in order to justify continued funding to such a broad range of interested parties, CORFO has to provide numerous outsourced, independent evaluations of every programme that it undertakes.

The outcomes analysed here suggest that to the extent that government institutions seeking to promote SMEs are market-driven and possess autonomy, they will have higher levels of accountability. However, autonomy alone may not be enough for private institutions working in this area. Our findings suggest that private agencies, even highly autonomous ones such as SEBRAE, need to take steps to ensure their accountability. One practical suggestion for agencies with this kind of structure is that they make sure to build this sort of systematic, outside evaluation of the impact of their programmes into their practices. 


\section{Bibliography}

Alburquerque, F. (1997): The importance of local production and small-scale enterprises for Latin American development, CEPAL Review, No. 63, LC/G.1986-P, Santiago, Chile, Economic Commission for Latin America and the Caribbean (ECLAC), December.

ALIDE (Latin American Association of Development Financing Institutions) (1993): Liberalización financiera y Banca de Desarrollo, Lima.

Bresser-Pereira, L.C. (1992): The crisis of the State approach to Latin America, Conference Paper, Latin American Studies Association (LASA).

Burk, S.J. and G.E. Perry (1998): Beyond the Washington Consensus: Institutions matter, Washington, D.C., World Bank.

Castillo, M. (1993): El rol de la Banca de Fomento en el contexto de la liberalización financiera: el caso de Chile, Liberalización financiera y Banca de Desarrollo, Lima, Latin American Association of Development Financing Institutions (ALIDE).

Castillo, M. and C. Cortellese (1988): Small and medium-scale industry in the development of Latin America, CEPAL Review, No. 34, LC/G.1521-P, Santiago, Chile, Economic Commission for Latin America and the Caribbean (ECLAC), April.

Edwards, S. (1995): Crisis and reform in Latin America: From despair to hope, New York, Oxford University Press.

Held, G. (1995): Políticas de financiamiento de las empresas de menor tamaño: experiencias recientes en América Latina, Financiamento del desarrollo series, No. 34, LC/L.911, Santiago, Chile, Economic Commission for Latin America and the Caribbean (ECLAC), October.

ILO (International Labour Organization) (1972): Employment, incomes and equality: A strategy for increasing productive employment in Kenya, Geneva.

NAFIN (Nacional Financiera, S.N.C.) (1997): Informe anual, 1997, Mexico City.
(1998): Informe anual, 1998, Mexico City.

OECD (Organisation for Economic Co-operation and Development) (2002): South America: Forum for Enterprise Development, Paris.

Peres, W. and G. Stumpo (2000): Small and medium-sized manufacturing enterprises in Latin America and the Caribbean under the new economic model, World Development, vol. 28, No. 9.

(2002): Pequeñas y medianas empresas industriales en América Latina y el Caribe, Mexico City, Siglo Veintiuno Editores.

Puente, J., J.J. Llisterri and J. Rivas (1998): Inter-American Development Bank Group activities supporting small and medium-sized enterprises (1990-1998), Washington, D.C., July.

Rosales, O. (1988): An assessment of the structuralist paradigm for Latin American development and the prospects for its renovation, CEPAL Review, No. 34, LC/G.1521-P, Santiago, Chile, Economic Commission for Latin America and the Caribbean (ECLAC), April.

Stiglitz, J.E. (1998): More instruments and broader goals: Moving toward the post-Washington consensus, The 1998 WIDER Annual Lecture, Helsinki, 7 January.

Suzigan, W. and A.V. Villela (1997): Industrial Policy in Brazil, Campinas, Institute of Economics, State University at Campinas (Unicamp).

The Donor Committee (1997): Business development services for SMEs, Washington, D.C.

Williamson, J. (comp.) (1990): What Washington means by policy reform, Latin American adjustment: How much has happened?, Washington, D.C., Johns Hopkins University Press.

World Bank (1993): The East Asian miracle: Economic growth and public policy, Washington, D.C. 